\title{
Studying the Social History of a Russian Microregion, Based on Historical Maps and Aerial Survey
}

\author{
E. S. Grishin, V. V. Kanishchev, K. S. Kunavin, S. K. Lyamin, D. S. Zhukov
}

For citation: Grishin E. S., Kanishchev V.V., Kunavin K.S., Lyamin S. K., Zhukov D. S. Studying the Social History of a Russian Microregion, Based on Historical Maps and Aerial Survey. Vestnik of Saint Petersburg University. History, 2021, vol. 66, issue 3, pp. 990-1011.

https://doi.org/10.21638/11701/spbu02.2021.317

This study focused on a Russian agrarian microregion $\left(12.5 \mathrm{~km}^{2}\right)$ situated in a forest steppe area (in Tambov Oblast) during the $18^{\text {th }}-19^{\text {th }}$ centuries. The research illuminates the mech-

Evgeniy S. Grishin - Head of the Sector for Historical Cartography and Geographic Information Systems, the Russian Presidential Academy of National Economy and Public Administration, 82, pr. Vernadskogo, Moscow, 119606, Russian Federation; grishin-es@ranepa.ru

Евгений Сергеевич Гришин - руководитель сектора исторической картографии и геоинформационных систем, Российская академия народного хозяйства и государственной службы при Президенте Российской Федерации, Российская Федерация, 119606, Москва, пр. Вернадского, 82; grishin-es@ranepa.ru

Valery V. Kanishchev - Dr. Sci. (History), Professor, G. R. Derzhavin Tambov State University, 33, Internatsionalnaya ul., Tambov, 392000, Russian Federation; kanishev@tsutmb.ru

Валерий Владимирович Канищев - д-р ист. наук, проф., Тамбовский государственный университет имени Г. Р. Державина, Российская Федерация, 392000, Тамбов, ул. Интернациональная, 33; kanishev@tsutmb.ru

Konstantin S. Kunavin - PhD (History), Leading Research Fellow, Laboratory for Social History, G. R. Derzhavin Tambov State University, 33, Internatsionalnaya ul., Tambov, 392000, Russian Federation; kunavin@tsutmb.ru

Константин Сергеевич Кунавин - канд. ист. наук, вед. науч. сотр., лаборатория социальной истории, Тамбовский государственный университет имени Г. Р. Державина, Российская Федерация, 392000, Тамбов, ул. Интернациональная, 33; kunavin@tsutmb.ru

Sergey K. Lyamin - PhD (History), Associate Professor, G. R. Derzhavin Tambov State University, 33, Internatsionalnaya ul., Tambov, 392000, Russian Federation; lyamin@tsutmb.ru

Сергей Константинович Лямин - канд. ист. наук, доц., Тамбовский государственный университет имени Г.Р.Державина, Российская Федерация, 392000, Тамбов, ул. Интернациональная, 33; lyamin@tsutmb.ru

Dmitry S. Zhukov - PhD (History), Associate Professor, G. R. Derzhavin Tambov State University, 33, Internatsionalnaya ul., Tambov, 392000, Russian Federation; zhukov@tsutmb.ru

Дмитрий Сергеевич Жуков - канд. ист. наук, доц., Тамбовский государственный университет имени Г.Р.Державина, Российская Федерация, 392000, Тамбов, ул. Интернациональная, 33; zhukov@tsutmb.ru

This research was supported by the Russian Science Foundation, grant No. 19-18-00322 "A comparative-historical study of anthropogenic landscapes in different regions by means of unmanned aerial vehicles (Tambov region and Udmurtia, mid- $18^{\text {th }}-$ early $20^{\text {th }}$ centuries)".

Исследование выполнено за счет гранта Российского научного фонда, проект № 19-18-00322 «Сравнительно-историческое изучение антропогенных ландшафтов различных регионов средствами беспилотных летательных аппаратов (Тамбовская область и Удмуртия, середина XVIII - начало $\mathrm{XX}$ в.)».

(C) St. Petersburg State University, 2021 
anisms, patterns, and impact that the environment has on social processes, and vice versa the human impact on the environment (and particularly on landscape). The authors created a geographic information system which they used to compare the results of aerial survey and satellite imagery, with historical maps and other sources, including archival documents. Morphological anomalies were identified on an orthophotomap, and then interpreted. The conclusions of the research concern the nature of interaction between the agrarian society and the environment. Settlement in the plains of the forest steppe was heavily dependent on the water regime, which directly affected the condition and dynamics of communication routes and economic infrastructure. The vanished settlement found in this study is an example of such an effect: it grew up along a road and was abandoned when the areas through which the road ran were waterlogged. Plain rivers can alter the surrounding landscape quite drastically over relatively short historical periods, and are themselves subject to anthropogenic influence. Changes in living conditions and economic management led to variability in settlement patterns and land use. This can be seen especially well in the lowland, where such schemes were predominantly temporary. The processing of Earth remote sensing data makes it possible to fill gaps in sources and discover new evidence of the past.

Keywords: history, microregion, agrarian society, environment, historical maps, Earth remote sensing.

\title{
Исследование социальной истории российского микрорегиона на основе исторических карт и аэрофотосъемки
}

\author{
Е. С. Гришин, В. В. Канищев, К. С. Кунавин, С. К. Лямин, Д. С. Жуков
}

Для цитирования: Grishin E. S., Kanishchev V. V., Kunavin K. S., Lyamin S. K., Zhukov D. S. Studying the Social History of a Russian Microregion, Based on Historical Maps and Aerial Survey // Вестник Санкт-Петербургского университета. История. 2021. Т. 66. Вып. 3. С. 990-1011.

https://doi.org/10.21638/11701/spbu02.2021.317

Исследование сфокусировано на российском аграрном микрорегионе $\left(12,5\right.$ км²$\left.^{2}\right)$ в лесостепной зоне (Тамбовская обл.). Хронологические рамки: XVIII-XXI вв. Целью является разъяснение механизмов, закономерностей и результатов воздействия природной среды на социальные процессы и наоборот - человека на природную среду (в частности, на ландшафт). Авторы создали геоинформационную систему, посредством которой сопоставили результаты аэрофотосъемки и спутниковых снимков с историческими картами и иными историческими источниками, в том числе с архивными документами. Аэрофотосъемка была проведена специально для данного исследования. Впервые в отечественной историографии предпринята попытка реконструировать социальную историю лесостепного микрорегиона совместно с историей ландшафта на основе методов и материалов, традиционно используемых в естественно-научных и археологических изысканиях. Был проведен поиск морфологических аномалий на ортофотоплане, выполнена их интерпретация. В результате сделаны выводы относительно характера взаимодействия аграрного общества со средой. Расселение в равнинных районах лесостепи сильно зависело от водного режима, который прямо воздействовал на состояние и динамику путей сообщения и хозяйственной инфраструктуры. Пример такого воздействия - обнаруженное в этом исследовании исчезнувшее поселение, которое возникло вдоль дороги и было оставлено в результате заболачивания участков, через которые эта дорога пролегала. Равнинные реки весьма сильно изменяют близлежащий ландшафт на сравнительно коротких исторических отрезках, а также сами подвержены антропогенному влиянию. Изменение условий жизни и хозяйствования вело к изменчивости схем расселения и землепользования. Особенно хорошо это прослежива- 
ется на низком берегу, где такие схемы были преимущественно временными. Показана принципиальная возможность использования аэрофотоснимков и спутниковых снимков в исторических изысканиях, относящихся к XIX-XX вв. Дистанционное зондирование земли среди прочего позволяет восполнить лакуны в источниках и дает возможность обнаружить новые свидетельства прошлого.

Ключевые слова: история, микрорегион, аграрное общество, природная среда, исторические карты, дистанционное зондирование земли.

\section{Object and objectives}

This case study focuses on a small plot $\left(12.5 \mathrm{~km}^{2}\right)$ in Znamensky District, Tambov Oblast, Central Russia (Fig. 1). Its development started in the $18^{\text {th }}$ century, and the chronological framework of this study involves the $18^{\text {th }}$ to $21^{\text {st }}$ centuries. This plot was chosen as being typical of the Russian forest steppe, as well as being provided with sufficient historical sources. The plot, despite its modest size, demonstrates diversity: there are forests, remnants of the steppe, arable land, large villages, roads, rivers, and streams. All this has the potential to ensure a survey is heuristically productive, and gives hope that the results and the methods developed could be extended to significantly larger territories.

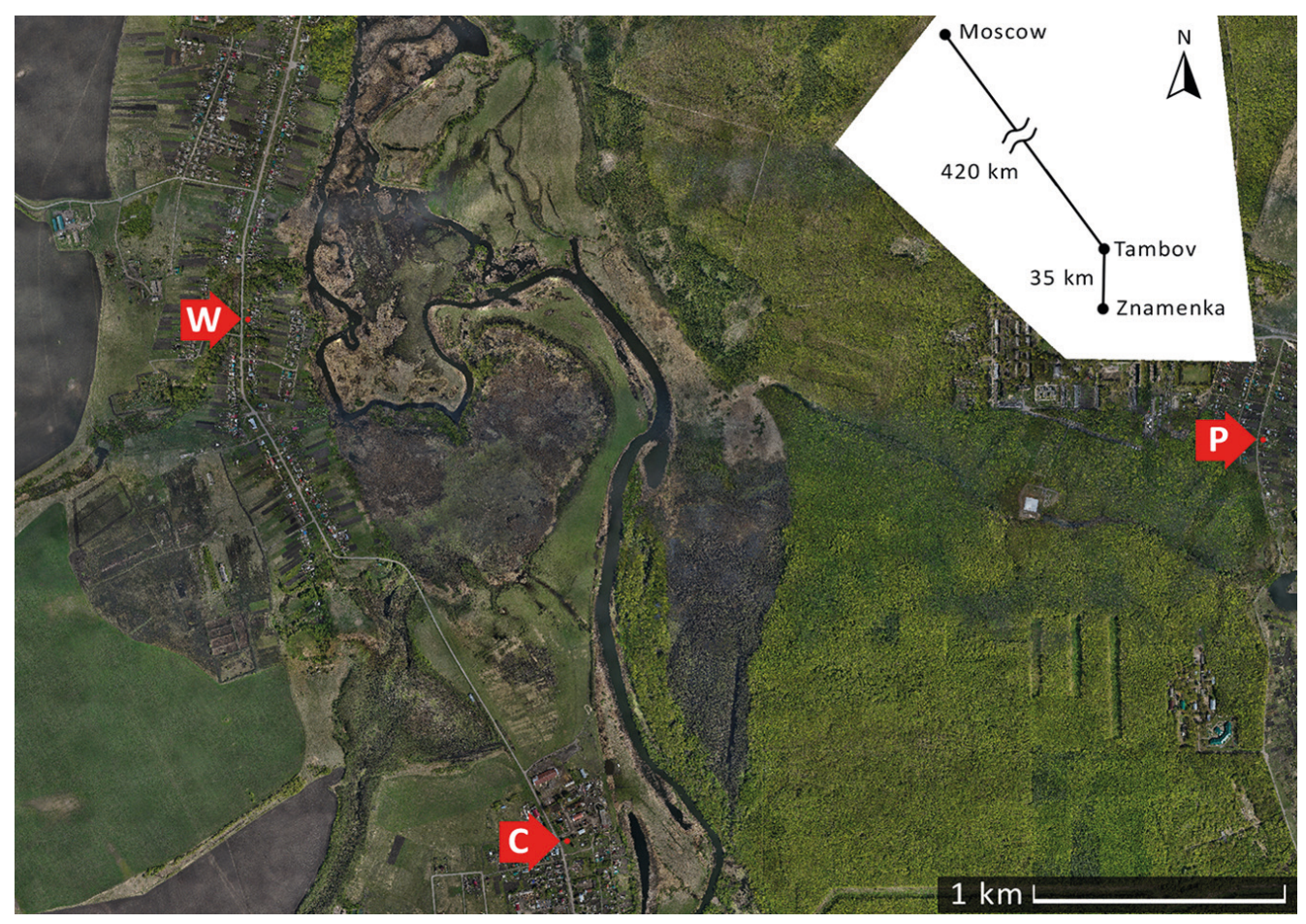

Fig. 1. Examined plot. Orthophotomap, 2019. The white polygon in the upper right corner indicates that there is no image. Coordinates of the markers: $C-52.433571,41.432385$, urban-type settlement Znamenka; $W$ - 52.452505, 41.414704, Vorontsovka village; $P$ - 52.447104, 41.473756, Pervomaiskoe settlement. Aerial photography was performed, and the orthophotomap was created by Finko LLC (Izhevsk) by order of the Derzhavin Tambov State University within the framework of the project of the Russian Science Foundation No. 19-18-00322 
Once we had selected and organised aerial photography, some additional circumstances became clear: there had been intense military activity in this area, both in the past and present.

This study aims to clarify the mechanisms, patterns, and impact of the natural environment on social processes and vice versa: the human impact on the natural environment (and in particular, on the landscape). The cutting-edge tool used for approaching such problems entails a comparison of aerial and satellite imagery data with historical maps and other historical sources. We assessed the usefulness of methods of processing remote sensing data of the Earth for studying relatively recent history.

\section{Literature}

There is extensive landscape history literature on methods for analysing historical maps in comparison with remote sensing data. Anthropogenic impact has become one of the key drivers of environmental change, and the relevant methodological developments can be adapted to the purposes of historical research. In order to do so, it is necessary to switch the focus of the research lens for the history of ecology from the environment in which humans live and act, to the humans who live and act in a specific environment.

We made extensive comparisons of historical maps in our research. Despite being arduous, this technique has been used in many studies with high heuristic productivity. Such surveys are usually focused on relatively small areas: for example, the vicinity of Bormio (Italian Alps) ${ }^{1}$, the Guanarteme dune field (Canary Islands, Spain) ${ }^{2}$, settlements in southern Palestine ${ }^{3}$, the Morava river floodplain (Czech Republic) ${ }^{4}$, and the Sorrento Peninsula ${ }^{5}$ (Italy). The scope of these studies ranges from several decades ${ }^{6}$ to 200 years and more ${ }^{7}$. A number of works ${ }^{8}$ have reconstructed the dynamics of different land categories (primarily forests). Modern orthophotomaps were utilised in some of these works as the final chronological point. GIS software provides tools for identifying and accurately

1 Velli A., Pirola A., Ferrari C. Evaluating landscape changes using vegetation and land-use maps: An integrated approach // Landscape Research. 2019. Vol. 44, iss. 6. P.768-781.

2 Santana-Cordero A., Monteiro-Quintana M.L., Hernández-Calvento L. Reconstructing the environmental conditions of extinct coastal dune systems using historical sources: The case of the Guanarteme dune field (Canary Islands, Spain) // Journal of Coastal Conservation. 2014. Vol.18, iss. 4. P. 323-337; Santana-Cordero A. M., Monteiro-Quintana M. L., Hernández-Calvento L. Reconstruction of the land uses that led to the termination of an arid coastal dune system: The case of the Guanarteme dune system (Canary Islands, Spain), 1834-2012 // Land Use Policy. 2016. Vol. 55. P.73-85.

3 Levin N., Kark R., Galilee E. Maps and the settlement of southern Palestine, 1799-1948: An historical/ GIS analysis // Journal of Historical Geography. 2010. Vol. 36, iss. 1. P. 1-18.

4 Machar I., Servus M. Linking historical research with restoration ecology in the floodplain landscape case study: Landscape-ecological study and management plan of the Tovačov lakes (Czech Republic) // Journal of Landscape Ecology. 2010. Vol.3, iss. 1. P. 16-41.

5 Pindozzi S., Cervelli E., Capolupo A., Okello C., Boccia L. Using historical maps to analyze two hundred years of land cover changes: Case study of Sorrento peninsula (south Italy) // Cartography and Geographic Information Science. 2016. Vol. 43, iss. 3. P. 250-265.

6 Velli A., Pirola A., Ferrari C. Evaluating landscape changes using vegetation and land-use maps.

7 Pindozzi S. et al. Using historical maps...

8 Skaloš J., Engstová B. Methodology for mapping non-forest wood elements using historic cadastral maps and aerial photographs as a basis for management // Journal of Environmental Management. 2010. Vol. 91, iss. 4. P. 831-843; Skaloš J., Engstová B., Trpáková I., Šantrůčková M., Podrázský V. Long-term changes in forest cover 1780-2007 in central Bohemia, Czech Republic // European Journal of Forest Research. 2012. Vol. 131, iss. 3. P. 871-884. 


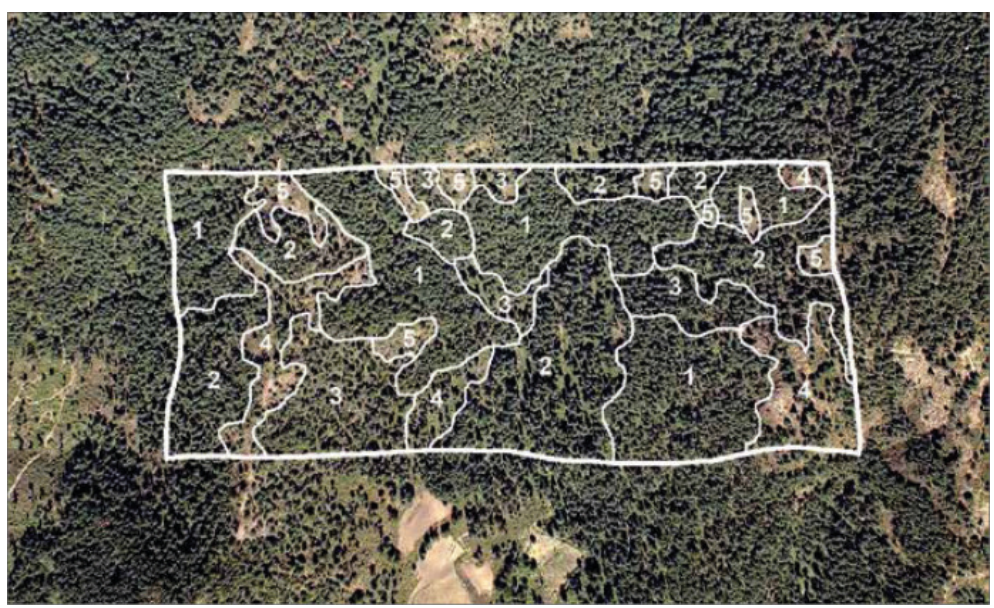

Fig. 2. Interpretation of different categories of forest cover. The central part of the image is the photointerpretable area, separating densities of forest cover: 1 - closed; 2 - semi-closed; 3 - semi-open; 4 - open; 5 deforested [López García J., Prado Molina J., Manzo Delgado L., Peralta Higuera A., 2016]

describing the historical dynamics of objects" ${ }^{9}$ The authors of many of these studies took as their premise a thesis which also inspired Velli and colleagues: "Changes in land use are considered to be the most significant alteration in the Earth's surface, with numerous implications ranging from biodiversity alteration to a decrease in human well-being" ${ }^{10}$. We hold this position in our work too. Bürgi and colleagues describe some approaches to identifying anthropogenic impact ${ }^{11}$. A number of reviews present the methodology for manual and computer interpretation of aerial photographs and other remote sensing data in some detail ${ }^{12}$.

Manual processing relies on the expertise of the interpreter. Although this procedure cannot be completely free from subjectivity, its significant advantage is the ability of a human to understand complex non-standard images. Manual interpretation comes down to two operations: 1) determining the boundaries of polygons (areas with similar proper-

9 Santana-Cordero A.M., Szabó P. Exploring qualitative methods of historical ecology and their links with qualitative research // International Journal of Qualitative Methods. 2019. Vol. 18. P. 1-11.

10 Velli A., Pirola A., Ferrari C. Evaluating landscape changes using vegetation and land-use maps. P.768.

11 Bürgi M., Russell E. W. B. Integrative methods to study landscape changes // Land Use Policy. 2001. Vol.18, iss. 1. P.9-16; Bürgi M., Hersperger A. M., Schneeberger N. Driving forces of landscape change current and new directions // Landscape Ecology. 2004. Vol. 19, iss. 8. P. 857-868; Bürgi M., Straub A., Gimmi U., Salzmann D. The recent landscape history of Limpach valley, Switzerland: Considering three empirical hypotheses on driving forces of landscape change // Landscape Ecology. 2010. Vol. 25, iss. 2. P. 287-297.

12 Morgan J.L., Gergel S.E., Coops N.C. Aerial photography: A rapidly evolving tool for ecological management // BioScience. 2010. Vol.60, iss. 1. P.47-59; Zhurbin I. V., Borisov A. V., Nazmutdinova A.I., Milich V.N., Petrov R.P., Ivanova M. G., Modin R. N., Kniazeva L.F., Vorobeva N. G., Zinchuk S. V. The use of remote sensing, geophysical methods and soil analysis in the study of sites disturbed by agricultural activity // Arkheologiya, etnografiya i antropologiya Yevrazii. 2019. Vol.47, no. 2. P.103-111; Zhukov D. S., Lyamin S. K., Kunavin K.S. Experience in using aerial photography and historical maps in historical research: Literature, methods, cases // Innovatika i ekspertiza. 2019. Iss. 3 (28). P. 44-63. 
ties) on an orthophotomap or satellite image; and 2) interpreting the resulting polygons (in other words, identifying what a particular polygon actually represents on the ground). This is done with GIS software, where polygons are drawn on a separate layer (or layers) and then classified.

Fig. 2 demonstrates how specific plots are marked on an aerial photograph ${ }^{13}$. In this particular case, areas were identified in woodland that contrasted in terms of tree cover density. Such markings provide material for studying the structure and dynamics of woodland (in particular, deforestation processes). We also employed manual marking in this study. This technique, based on several characteristics (colour, texture, etc.), was used to identify specific areas and objects, which were then interpreted.

Interpretation is always based on the classification of objects. The existing standard classifications, in most cases, are of little use for the purposes of historical research, and therefore authors usually devise their own classifications (sometimes based on existing ones) ${ }^{14}$. The computerised interpretation of remote sensing data (in particular, satellite imaging) makes it possible to process big data. Examples of the successful application of such methods include studies ${ }^{15}$ that show the dynamics of anthropogenic activities over vast areas in national reserves.

A group of American researchers studied changes in the landscape in the valley of the Saint Croix River (from 1830 to the present). Andersen and colleagues compared the dynamics of landscape changes with the social history of the region, and obtained meaningful results. The researchers concluded that anthropogenic impact had been increasing non-evolutionarily. "Two periods of rapid change were identified. Change was rapid from 1850 to 1880 , as first loggers and then farmers converted a lightly populated landscape of oak savanna, prairie, mixed hardwood and conifer forests and wetlands, maintained by frequent fires, into a largely deforested agricultural landscape. A second period of rapid change was from 1940 to the present as the urban area has expanded outward. Urbanization has further fragmented the remaining areas of natural habitat..."16

Grossinger and colleagues have made a considerable effort to apply these methods to history ${ }^{17}$. The authors reconstructed the condition of woodlands and wetlands in the Coyote Valley (part of the Silicon Valley in California, USA). A large number of sources (maps, photographs, documents) were put together into a single GIS. Historical maps with information about the land cover were referenced to coordinates and compared with

${ }^{13}$ López García J., Prado Molina J., Manzo Delgado L., Peralta Higuera A. Monitoring changes of forest canopy density in a temperature forest using high-resolution aerial digital photography // Investigaciones Geográficas, Boletín del Instituto de Geografía. 2016. Vol. 2016, iss. 90. P. 59-74.

${ }_{14}$ Mackovčin P. Land use categorization based on topographic maps // Acta Pruhoniciana. 2009. Vol.91. P.5-13; Velli A., Pirola A., Ferrari C. Evaluating landscape changes using vegetation and land-use maps.

15 Song X., Huang Y., Fu J., Jiang D., Tian G. Spatial variability and ecological effects of anthropogenic activities in a nature reserve: A case study in the Baijitan National Nature Reserve, China // Sustainability. 2017. Vol.9, iss.2. P.1-14; Wan L., Zhang Y., Zhang X., Qi S., Na X. Comparison of land use / land cover change and landscape patterns in Honghe National Nature Reserve and the surrounding Jiansanjiang Region, China // Ecological Indicators. 2015. Vol.51. P. 205-214.

16 Andersen O., Crow T.R., Lietz S. M., Stearns F. Transformation of a landscape in the upper mid-west, USA: The history of the lower St. Croix river valley, 1830 to present // Landscape and Urban Planning. 1996. Vol.35, iss. 4. P. 247-267.

17 Grossinger R.M., Striplen C. J., Askevold R. A., Brewster E., Beller E. E. Historical landscape ecology of an urbanized California valley: Wetlands and woodlands in the Santa Clara Valley // Landscape Ecology. 2007. Vol. 22, iss. 1. P. 103. 
a 2002 orthophotomap. Land cover types that had been present before the development of the territory by North American colonists and before the beginning of intensive urbanisation were reconstructed. Such a reconstruction, from the point of view of the authors, results in the ideal condition of the territory, and is a reference point for planning the exploitation of natural resources. By comparing the reconstruction with the current condition, the authors were able to assess the condition of landscapes and ecosystems, and also to develop recommendations for their protection and restoration.

The Vorontsovka and Znamenka estates - which were famously advanced farms by Russian standards - located in the territory in question were historically and ecologically studied by $\mathrm{Khmel}^{18}$. Sociohistorical aspects of the topic were touched upon in collaborative works devoted to the computer reconstruction of historical and natural monuments on the Znamenka estate ${ }^{19}$.

\section{Topographic and geomorphologic characteristics of the plot}

The investigated plot is located in the forest steppe zone. The terrain is relatively flat. The height ranges from $160 \mathrm{~m}$ in the eastern area to $118 \mathrm{~m}$ in the river floodplain. The main hydrographical object is the Tsna River (Volga basin) flowing north. The riverbed forms a significant meander. The left bank of the Tsna near the village of Vorontsovka is higher bedrock. The right bank is gently sloping floodplain. The difference in height between the banks is 15 meters $(118-133 \mathrm{~m})$. The general character of the Tsna valley is determined by the asymmetric development of the territory in question: economic and social-cultural objects are located on the left bank. The right bank is replete with fluvial landforms: oxbow lakes, arroyos, and ravines. Part of the floodplain area is swampy, which is also noted in cartographic sources.

The flow velocity of the Tsna is $0.1 \mathrm{~m} / \mathrm{s}$. Considering the nature of the river's discharge and the general dynamics of channel processes, we can assume that the velocity of the river in the $18^{\text {th }}-19^{\text {th }}$ centuries was at the same level. The river was also full-flowing: many modern ravines used to be fully functional tributaries of the Tsna. Based on the velocity of the current, it can be argued that the bottom of the river is silty, which, accordingly, affects the composition of alluvial deposits in the floodplain. Among the fluvial forms that characterise the area, it is worth noting the old lake, indicated on the $18^{\text {th }}$ century map under the name of Bogoroditskoe. On later cartographic sources, the lake is swamped, and at present it has merged with the floodplain shore. Based on cartographic material, it can be argued that the Tsna has retained its general configuration, but the territory along its right bank shows significant changes - mainly associated with the emergence of fluvial landforms and the river's discharge regime.

${ }^{18}$ Khmel' E. V. Formirovanie ratsional'nogo prirodopol'zovaniia v khoziaistvakh krupnykh zemlevladel'tsev Tambovskoi gubernii v kontse XIX — nachale XX vv. Diss. ... kand. ist. nauk. Tambov, 2004.

19 Budiukina N.N., Kanishchev V.V., Konchakov R.B., Konchakov R.B.Mizis Iu.A. Prirashchenie istoricheskikh znanii v protsesse elektronnoi rekonstruktsii pamiatnikov istorii i kul'tury (po materialam dvorianskikh usadeb Tambovskoi gubernii)//Vestnik Tambovskogo universiteta. Seriia: Gumanitarnye nauki. 2013. Iss. 12. P. 411-419; Budiukina N. N., Glagoleva O. E., Kanishchev V. V., Mizis Iu. A. Istochnikovedcheskii analiz istoricheskikh dokumentov kak informatsionnogo potentsiala dlia komp'iuternoi rekonstruktsii russkoi dvorianskoi usad'by kontsa XVIII - nachala XX v. (po materialam Tambovskoi i Tul'skoi gubernii) // Vestnik Tambovskogo universiteta. Seriia: Gumanitarnye nauki. 2013. Iss. 1. P. 256-269. 


\section{Historical context}

The intensive economic development of the Tambov section of the forest steppe began after the Russian fortress of Tambov was founded $35 \mathrm{~km}$ north of the area under consideration (Tambov now is the regional centre) in 1636 . Until the $18^{\text {th }}$ century, however, the area had remained only marginally affected by agricultural activities. The population dynamics of the largest villages are presented in Table.

Population dynamics (compiled by V. V. Kanishchev)

\begin{tabular}{|l|c|c|c|c|}
\hline \multirow{2}{*}{\multicolumn{1}{|c|}{ Village $^{\mathbf{2 0}}$}} & \multicolumn{4}{|c|}{ Population, inhabitants $^{\mathbf{2 1}}$} \\
\cline { 2 - 5 } & End of $\mathbf{1 8}^{\text {th }}$ century & Mid-19 $^{\text {th }}$ century & $\mathbf{1 9 1 6}$ & $\mathbf{2 0 1 0}$ \\
\hline $\begin{array}{l}\text { Znamenka, } \\
\text { Znamenskoe, } \\
\text { Zagryazhskoe, Karian }\end{array}$ & 999 & 1451 & 2659 & 6167 \\
\hline Sergeevka & - & - & 559 & - \\
\hline Vorontsovka & 563 & $\begin{array}{c}\text { (with adjoining } \\
\text { hamlet) }\end{array}$ & 1552 & 982 \\
\hline Baraki, Pervomaiskoe & - & - & - & 2485 \\
\hline
\end{tabular}

Two large estates were founded in the $18^{\text {th }}$ century by representatives of the noble Vorontsov and Zagryazhsky families. These estates would pass to different owners in the following decades, the most famous of whom were the Stroganovs and the Shcherbatovs in Znamenka.

Large villages experienced a sharp increase in population in the $19^{\text {th }}$ century. This stimulated an increase in the number of settlements: new small villages had formed through resettlement from large villages. Peasants resettled by the landowners in Znamenka formed the villages of Izmailovka, Malaya and Bolshaya Aleksandrovka, and Ivanovka ${ }^{22}$. Even after the resettlement of some peasants, however, there was rapid population growth in Znamenka before the peasant reform of 1861. The number of peasants then decreased because the Stroganovs provided them with small nadels (plots), which were inadequate for efficient farming. As a result, a significant proportion of the young population left the village. The population growth rate in Vorontsovka in the pre-revolutionary years was low in comparison with the average for the province. There was thus a relatively low demographic burden on the natural environment here at the beginning of the $20^{\text {th }}$ century.

20 Some village names have changed.

21 Alfavit dacham i zamezhevannym v nekotorye iz nikh seleniiam i pustosham Tambovskoi gubernii i yeya zhe uezda // Russian State Archive of Early Acts (RGADA). F. 1354. Op. 490. Parts 1-2. Alph. 199. L. 2, 4; Ekonomicheskie primechaniia dach Tambovskogo uezda // RGADA. F.1355. Op.1. D. 1649. L.3, 5; Opisanie dach $\mathrm{k}$ karte Tambovskogo uezda s ukazaniem nazvaniia dach, kolichestva zemli i vladel'tsev // RGADA. F.1357. Op. 1. D.269. L. 8, 14; Spisok naselennykh mest Tambovskoi gubernii na 1862 god. St. Petersburg, 1866; Spisok naselennykh punktov Tambovskoi gubernii. Tambov, 1916; Dokumenty Vserossiiskoi sel'skokhoziaistvennoi perepisi 1917 g. po Tambovskomu uezdu // State Archives of the Tambov Region (GATO). F. 143. Op. 3. D. 771. L. 7, 19; Itogi vserossiiskoi perepisi naseleniia 2010 g. T. 1: Chislennost' i razmeshchenie naseleniia. Tambovskaia oblast'. Tambov, 2012.

${ }^{22}$ Murav'ev N. I. Izbrannye kraevedcheskie trudy. Vol. 1. Tambov, 2006. P. 15, 48. 
In the late $19^{\text {th }}$ to early $20^{\text {th }}$ century, the Vorontsov and Znamenskoe estates were economically exemplary, and the sustainable use of natural resources was widely introduced. It is important to take into account that not only were natural resources being depleted here in the process of agricultural activity, but they were also being partially restored, which was a rare phenomenon in Russia at that time.

The population growth of Znamenka in the $20^{\text {th }}$ century is associated with the transformation of the village into a regional centre and an urban-type settlement, with a relatively large industrial sector and, consequently, an increased impact on the natural environment. The population of Vorontsovka was considerably high in 2010, and three times as high as the average Tambov village. The emergence of the village of Pervomaiskoe, which was large both physically and population-wise, on previously uninhabited territory apparently led to significant changes in the natural environment.

\section{Sources}

The principle source is an orthophotomap made in 2019 (hereinafter referred to as the orthophotomap-2019) shown in Fig. 1. We also used satellite images of the territory available in the Yandex.Maps ${ }^{23}$ and Google Maps ${ }^{24}$ services. The fact that these pictures were taken at different times of the year, in summer and spring, respectively, was very valuable for the study. The orthophotomap-2019 has a higher resolution than the available satellite images: $5 \mathrm{~cm}$ per pixel for the RGB channel and $10 \mathrm{~cm}$ per pixel for the other channels. The maximum resolution of images on Google Maps and Yandex.Maps is $50-60 \mathrm{~cm}$ per pixel.

As a result of two series of aerial photography (in May and June), we obtained 21 data layers (effectively, 21 orthophotomaps) in different spectral ranges. "Since different objects on Earth's surface have different reflection spectra, obtaining information in the form of several spectral channels makes it possible to classify objects in the image"25. Many of the identified anomalies found on the orthophotomap-2019 are absent or poorly visible on satellite images.

Several historical maps and plans were also utilised:

1. Plan of General Land Survey in Tambovskii uyezd, created at the end of the $18^{\text {th }}$ century (PGLS-XVIII) (Fig. 3).

2. The topographic boundary atlas (Mende-1860) was created in the late 1840s-1850s by the Land Survey Department and the Corps of Military Topographers under the general leadership of Lieutenant General A.I. Mende. The Mende-1860 map is distinguished by high detail and a variety of mapped objects.

3. A military Topographic map of the Russian Empire, compiled from 1846 to 1863 (MTM-1863) (Fig. 4).

4. The Red Army Map, 1937-1941 (RA-1941).

${ }^{23}$ Satellite image of the studied area in Yandex.Maps. URL: https://yandex.ru/maps/?l=sat\%2Csk$1 \& 1 \mathrm{l}=41.469001 \% 2 \mathrm{C} 52.428619 \&$ source $=$ wizgeo\&utm_medium $=$ maps-desktop\&utm_source $=$ serp $\& \mathrm{z}=14$ (accessed: 01.08.2020).

${ }^{24}$ Satellite image of the studied area in Google Maps. URL: https://www.google.ru/ maps/@52.440625,41.457875,5411m/data=!3m1!1e3?hl=ru (accessed: 01.08.2020).

${ }_{25}$ Korobov D. S. Primenenie GIS i dannykh distantsionnogo zondirovaniia v arkheologii // Mezhdistsiplinarnaia integratsiia v arkheologii: sbornik statei. Moscow, 2016. P.299. 


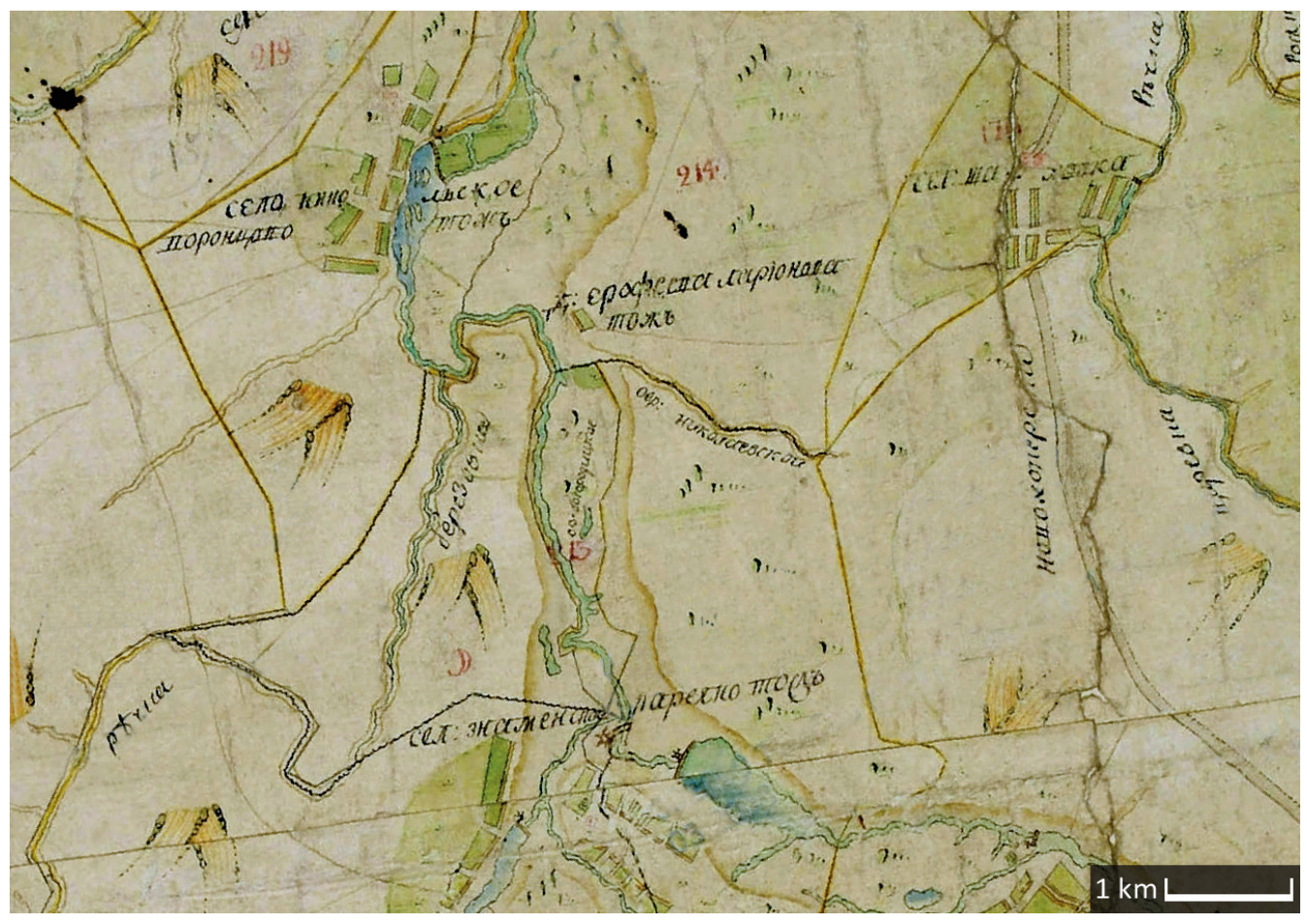

Fig. 3. PGLS, end of $18^{\text {th }}$ century [Plans of General Land Survey, Tambov province // Russia 4D. URL: http://russia4d.ru/content/plany-generalnogo-mezhevaniya-tambovskaya-guberniya]

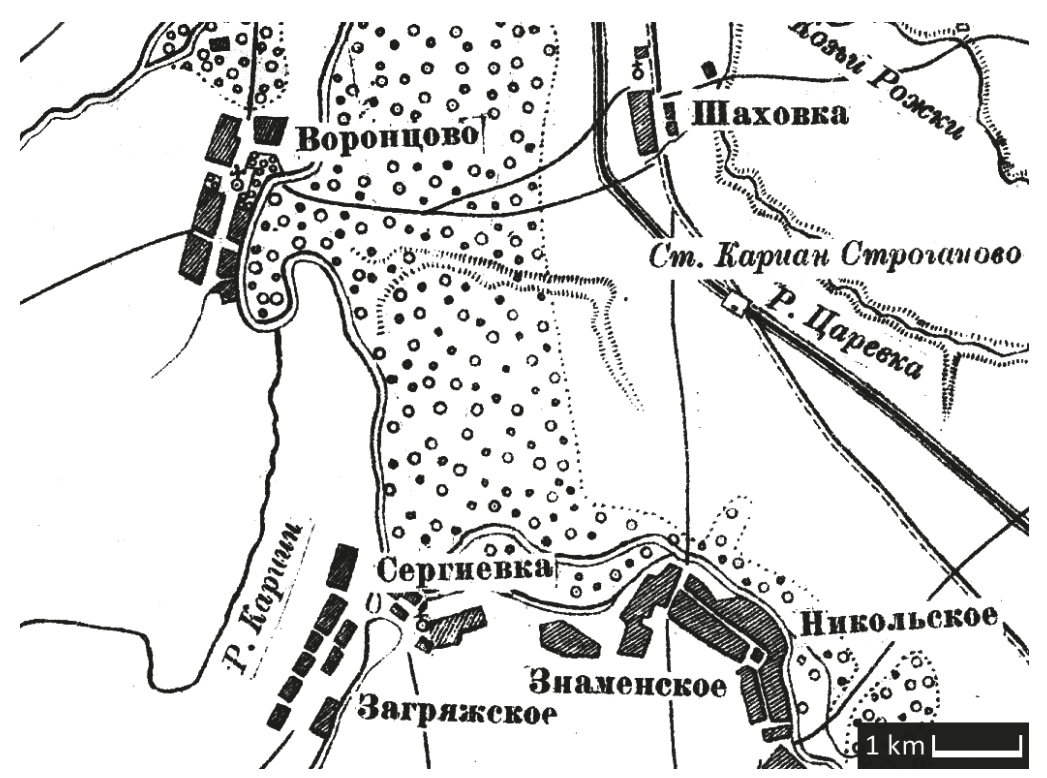

Fig. 4. MTM, 1846-1863. URL: http://www.etomesto.ru/shubert-map/17-19/ 


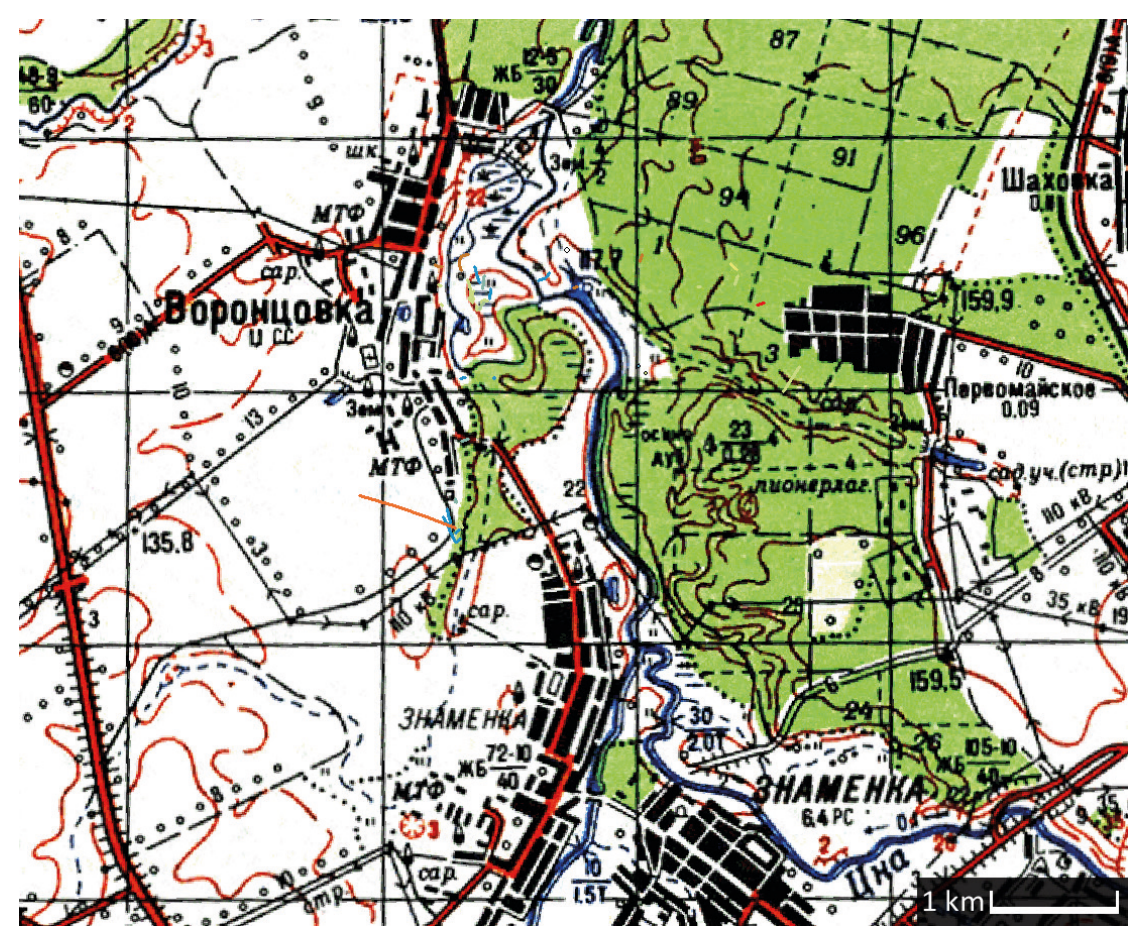

Fig. 5. TK-1992. URL: http://www.etomesto.ru/map-genshtab_n37-g/

Maps drawn between Mende-1860 and RA-1941 are either less informative or quote Mende-1860. More generalised medium-scale cartographic sources can clarify points of toponymy and the typology of objects, but they are insufficient as the main primary material in terms of their detail. The topographic map of the USSR/Russia was used (TK1992) (Fig. 5) as contemporary cartographic material. This is a current generation map, which has been further updated several times.

The list of cartographic materials in which the territory under consideration is presented is not limited to the above historical maps, however, many maps were essentially copies of other maps. It is important, therefore, to know when a survey was performed as the survey, and not all available maps, can be used to trace the dynamics of a landscape. In fact, there have been four generations of surveys in the area under consideration, reflected in PGLS-XVIII, Mende-1860, RA-1941, and TK-1992. We thus have the opportunity to rely on retrospective cartography. We also utilised plans for landlords' estates, such as the Stroganov/Shcherbatov estate.

An extensive set of written sources was used in the study: notes to the PGLS-XVIII and Mende-1860 maps, statistical records and office administration documents stored in the Russian State Archive of Early Acts (RGADA), and official statistical publications of the $19^{\text {th }}-21^{\text {st }}$ centuries. An article that includes a description of a typical Tambov village also located in a forest steppe area, several tens of kilometres from the plot under consideration $^{26}$, by the famous writer and publicist of the mid-19 $9^{\text {th }}$ century, the Tambov

${ }^{26}$ Gruzinov I. R. Vozmozhnost' uluchsheniia zhizni pomeshchich'ikh krest'ian (Tambovskaia guberniia) // Zhurnal zemledel'tsev. 1858. Vol. 4, no. 13. P.21-24. 
landowner I. R. Gruzinov, was useful for our research, as well as detailed depictions of the Znamenka estate written at the end of the $19^{\text {th }}$ century ${ }^{27}$.

The bulk of the sources are concentrated in the GIS that we created, which made it possible to compare them. In addition to the orthophotomap-2019, the GIS includes historical and contemporary maps as raster layers. The historical maps were referenced to the coordinates using the third order (polynomial) transformation method, which requires at least 12 control points for which the coordinates are known and unchanged over time. Due to the imperfection of some historical maps and especially plans, this operation leads to errors, which are noticeable, for example, in the case of PGLS-XVIII. Anomaly search results were also included in the GIS.

\section{Methods}

Among many methods for processing remote sensing data, the search for visual anomalies was chosen for this study. Anomalies are objects that differ in morphology and reflectivity from other objects of the same type that are located nearby. We focused on anomalies that could be traces of human impact on the original environment, or, conversely, traces of the absorption of anthropogenic landscapes by the natural environment as a result of abandonment. We believe that historical information can be encoded in anomalies. This methodology is actively used by archaeologists; however, we believe that it can also be productive for the study of the $18^{\text {th }}-21^{\text {st }}$ centuries.

The literature includes three main types of signs that indicate an anomalous object: "(1) characteristics of light, shadow, and contrast; (2) cropmarks, vegetation patterns; and (3) soil marks"28.

"The characteristics of light, shadow, and contrast are produced either by buildings above ground or partially destroyed or else by major anthropogenic changes in the landscape... The difference in vegetation on the surface is due to human intervention in the soil layer, which can alter its ability to store water or the process of grain crops maturation - both of which are limited by soil properties. Positive vegetation marks... appear due to better water storage capacity, when the vegetation in these areas stays green longer and is slightly taller than the surrounding flora. Negative marks are the result of disturbance of the soil layer in the form of walls or ramparts... In these places, the vegetation is lower and less resilient... Soil signs, as well as vegetation ones, are the product of human interference with the Earth's surface and depend on the water balance of the soil" 29 .

Since we were mainly interested in anomalies of anthropogenic origin, special attention was paid to the geometrically correct shape of the anomalies as well as the inconsistency with the context.

The search for anomalies was carried out on orthophotomap-2019 in each of the 21 channels. GIS is a working tool for the interpretation of anomalies as it allows to view

27 Velichko I. Kratkoe opisanie imeniia grafa Pavla Sergeevicha Stroganova Tambovskoi gubernii i uezda, pri sele Znamenskoe-Kareian. Moscow, 1893; Samodurov I. Kratkoe opisanie imeniia grafa P. Stroganova Tambovskoi gubernii i uezda pri sele Znamenskom-Kareiane. S prilozheniem 4-kh tablits za 30 let. Moscow, 1895.

${ }^{28}$ Korobov D. S. Primenenie GIS i dannykh distantsionnogo zondirovaniia v arkheologii. P. 294.

29 Ibid. 
them superimposed on aerial photographs, on modern and historical maps. Interpretation entails identifying the nature of objects and territories, as well as dating them.

A comparison of historical cartographic sources and written material with discovered anomalies enables, in many cases, to determine the occurrence or disappearance of anomalies. Traces of human activity are usually very strongly tied to the context: landscape and natural resources, economic infrastructure, road networks, systemically important objects, and so on. Humans and their activities depend on the geometry of space - both due to objective circumstances and due to the inertia of thinking. Since contexts change very quickly, then, as a rule, it is possible to establish which context a particular anomaly fits into.

This study focuses on examining a relatively small area, but its results can be used to decipher objects in wider adjacent territories. The created GIS functions, among other things, as an atlas of reference objects for such follow-up studies. Since a significant number of the interpretations made by us have been verified, the created GIS, in fact, contains markers that indicate certain traces of socio-economic history. This catalogue of markers will be further used to search for similar anomalies in other areas.

\section{Results}

The results of the search for anomalies are presented in Figs. 6-9, 11, and in a database available online: http://ineternum.ru/bd-a/. A detailed anomaly map superimposed on a satellite image is also available online: http://arcg.is/0GeCSy.

\section{Interpretation and verification}

The line marked on the Mende-1860 map (Fig. 6) is a road that no longer exists. Its remains are clearly visible on the orthophotomap-2019 and satellite images. It was not yet present at the end of the $18^{\text {th }}$ century (in PGLS-XVIII), and was no longer there on the RA-1941 map. It apparently disappeared due to the waterlogging of two sections $\left(Z_{1}\right.$ and $\mathrm{Z}_{2}$ ) which it used to cross.

By 1941, only the remains of this road had survived, as indicated on RA-1941. The RA-1941 map also shows the swampiness of the above two areas. The vanished road is important for an understanding of the settlement in the area under consideration. There was a logistical need for a road through the forest (east to west), however, it changed directions many times. This was obviously the result of the changeable situation on the right floodplain bank: flooding and waterlogging often forced the construction of new roads in other places. Communications turned out to be highly dependent on the dynamics of the environment, and settlements were able to emerge and disappear along these routes. Judging by PGLS-XVIII and Mende-1860, the road passed along the border of land plots (along the boundary), which was common in the $18^{\text {th }}-19^{\text {th }}$ centuries. This boundary road divided the land plots of two famous Russian noble families - those of the Vorontsovs and of the Zagryazhskys (land in the villages of Vorontsovka and Znamenka).

This road was possibly the most stable anthropogenic object found in the area under consideration. Now this non-functioning and forgotten road is the border between the Znamenskoye and Vorontsovskoye village councils (municipal units). In addition, there is now a windbreak planted on sections of this road (a number of trees and shrubs planted to 


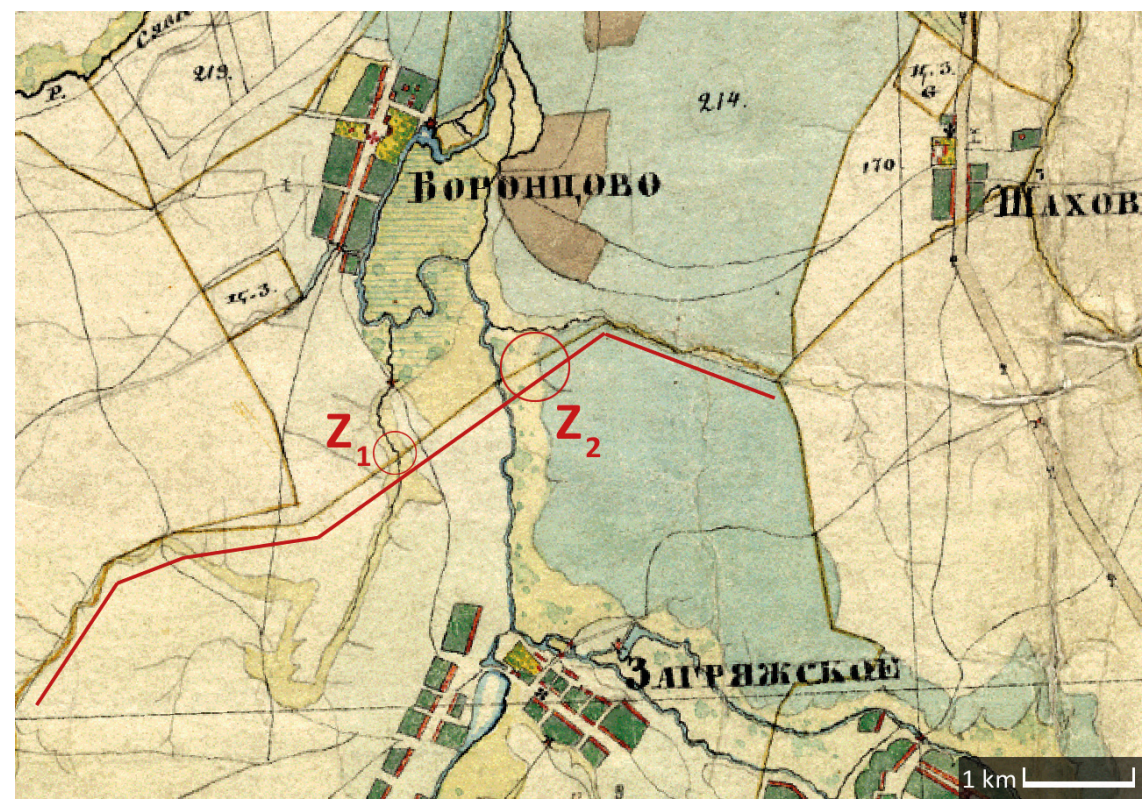

Fig. 6. Mende's map, 1860. Markers $\mathrm{Z}_{1}$ and $\mathrm{Z}_{2}$ are areas that later became waterlogged; red line is a road that no longer exists. Here and in Figs. 7, 8, 9, 11 and 13 red markers are added by the authors of the paper. URL: http://www.etomesto.ru/ map-tambov_mende/

protect arable land and other lands from soil erosion). These examples demonstrate that the development of land is determined not only by objective considerations, but also by the inertia of thinking.

An examination of orthophotomap-2019 made it possible to discover and partially reconstruct the history of a relatively large settlement. Anomalies marked in Fig. 7 A were

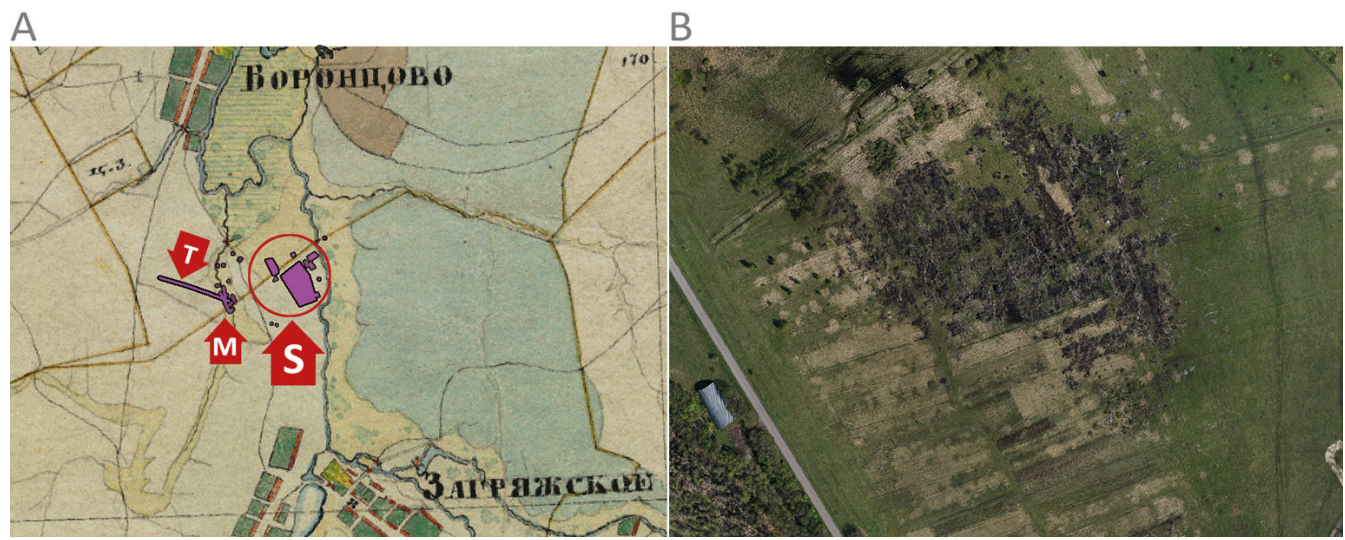

Fig. 7. Anomalies south of Vorontsovka (Vorontsovo): $A$ - Mende-1860; $B$ - object S on orthophotomap-2019. Anomalies are indicated by lilac polygons here and in Fig. 8. Marker S is a vanished settlement. Markers $\mathrm{M}$ and T are traces of land use structures and field road. URL: http://www.etomesto.ru/map-tambov_mende/ 
once collectively a settlement not known in written sources. This settlement was most likely a vyselki (a new settlement for peasants) from the village of Sergeevka. This settlement arose along the aforementioned road - according to our estimates, shortly after the mapping of Mende-1860. The settlement apparently disappeared after the road ceased to function. Nowadays it is a meadow. Orthophotomap-2019 (Fig. 7 B) shows the structure of the former residential land use in this area, which clearly indicates the traditional linear layout for local settlements.

On the plan of the Znamenskoe estate (1911), the land on which the settlement was located is specified as adjacent to the Sergeevka society (community) ${ }^{30}$. We believe that this provides a basis for the following reconstruction. Large Russian villages, such as Znamenka, were comprised of several communities (societies) which were registered inconsistently in the settlement statistics (sometimes separately, sometimes as part of one large settlement). This, accordingly, was reflected in the cartographic material. On the Mende-1860 map, the modern Znamenka is thus represented by one name, Zagriazhskoe; and on the MTM-1863, compiled a little later, the settlements Nikol'skoe, Znamenskoe, Zagriazhskoe, Sergievka (Sergeevka) are presented separately (Fig. 4).

Sergeevka has constantly featured as an independent settlement since the 1860s. The last mention of Sergeevka is in the 1975 administrative-territorial reference book of the Tambov region. It is clear from historical maps that the former separate village of Sergeevka again became part of a single Znamenka. The vyselki of Sergeevka, as we established, ceased to exist, but has left some anthropogenic traces in the landscape.

In Fig. 7 A, "T" denotes a trail which is now visible only on the orthophotomap-2019. The road that we discovered used to cross a stream, and there was a path from the bridge (marked "M" in Fig. 7 A) to the northwest. The trail had been in use at least up until the 1940s, when it probably adjoined another field road marked on RA-1941. The "M" in Fig. 7 A may also indicate remnants of land use structures (dams, diversion channels) that were designed to withstand floods and the waterlogging of the area.

The "B" in Fig. 8 indicates the anomaly which is now a swampy forest. This is clear from modern maps and satellite imagery. At the end of the $18^{\text {th }}$ century, this area was apparently also quite wet (among other things, Lake Bogoroditskoe is marked there). The lake was not marked on the Mende-1860 map, nor was the swamp; and a road passed through this territory. It can be assumed that this area was drier for some time in the $19^{\text {th }}$ century. The lands on the floodplain bank were in the border zone and unstable. Minor climate fluctuations or, perhaps, mild anthropogenic interference could have changed the character of this area rather quickly.

Such variability also determined the fate of the village of Erofeevo, which was located on the right bank, opposite Vorontsovka. Erofeevo is marked on PGLS-XVIII (Fig. 3) and on later maps: the Tambov district map of 1787 , and medium-scale maps of the early $19^{\text {th }}$ century. Erofeevo is absent on Mende-1860, however, and all subsequent maps. The road through the forest to this village has survived to this day and is used as a forest path to the beach on the Tsna River by the inhabitants of the village of Pervomaiskoe.

The vanished village was located in the southern part of Object D (Fig. 8), which is now a young coniferous forest (partially planted by humans). The felling was probably formed in several stages, and the process began in the pre-Soviet period. The openings of

30 Shchedrin K. Plan Tambovskoi gubernii Tambovskogo uezda usadebnoi chasti Znamenskogo imeniia vladeniia kniazia G. A. Shcherbatova // GATO. Collection of maps. 


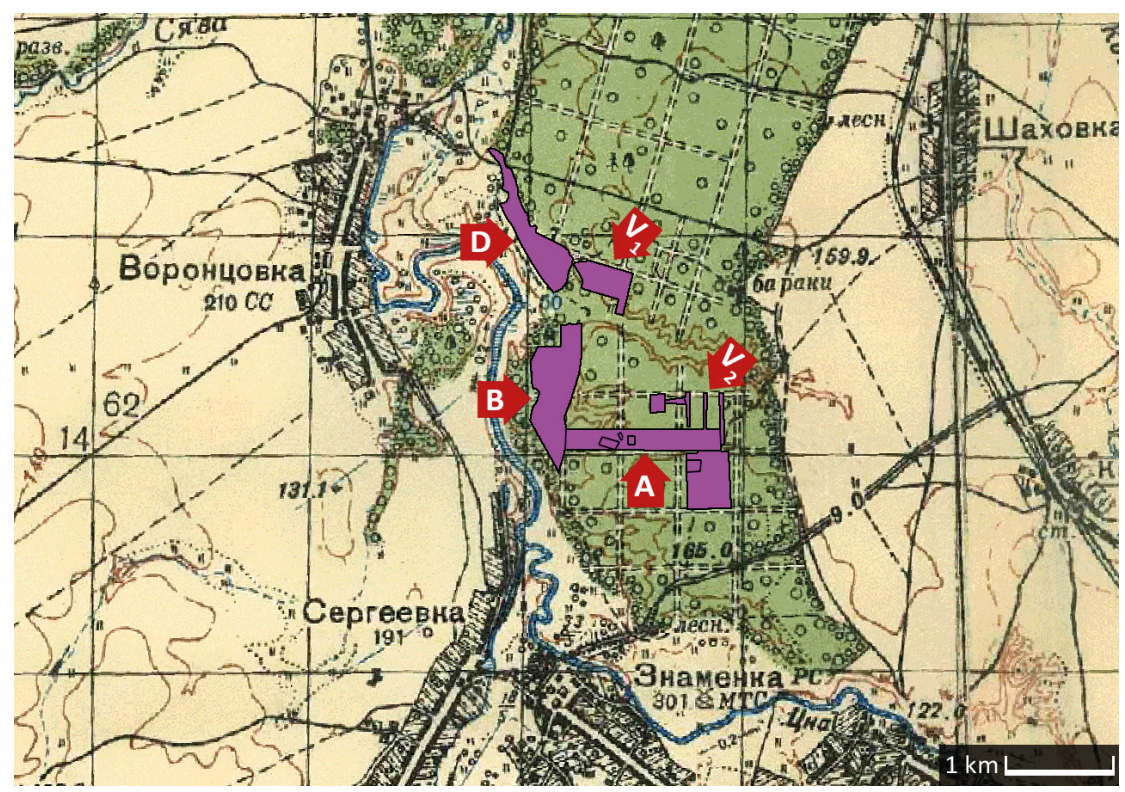

Fig. 8. RA-1941. Markers $\mathrm{V}_{1}$ and $\mathrm{V}_{2}$ are forest openings of the Soviet period. Markers A, B and D are forest cover anomalies. URL: http://www.etomesto.ru/maprkka_n-37-g/

the Soviet period have a specific character, and are visible in Fig. 9 A $\left(V_{1}, V_{2}\right)$. Such openings had a characteristic striped structure and, as a rule, they did not grow spontaneously but were planted in an orderly manner. In some cases, openings were planted with conifers, although deciduous trees predominate in the surrounding forest.

A pattern typical of openings is especially noticeable in the area adjacent to the explored plot from the north (Fig. 9 B).

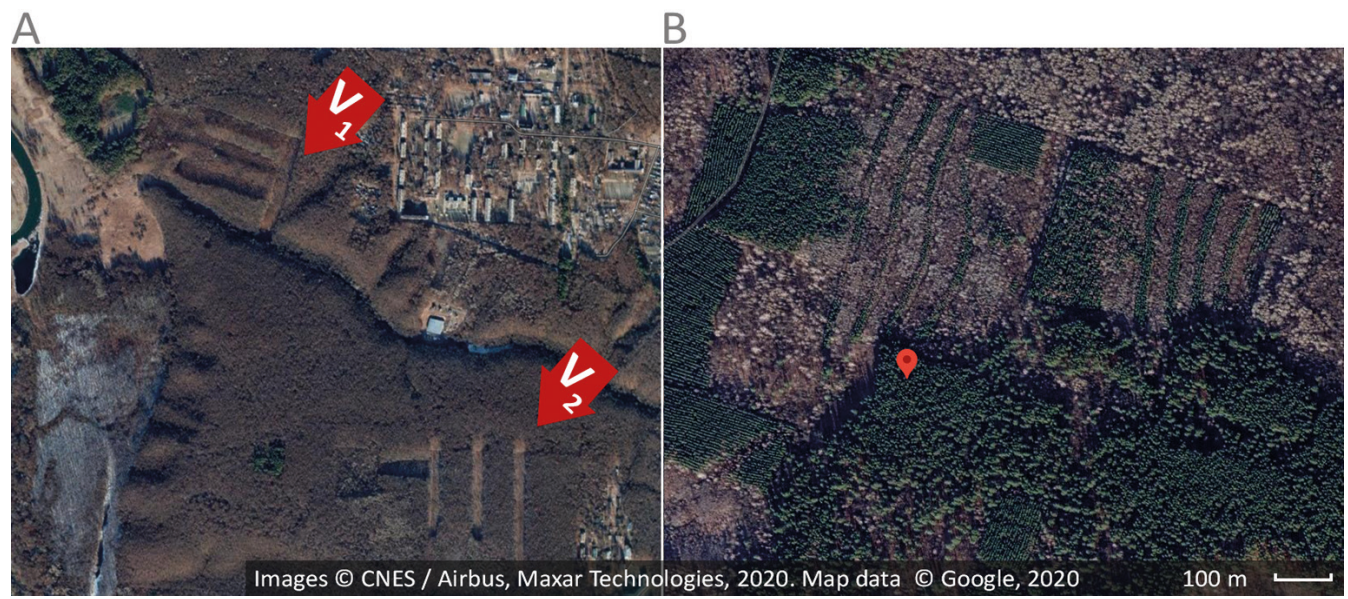

Fig. 9. Satellite images obtained via Google Maps: $A-$ objects $\mathrm{V}_{1}, \mathrm{~V}_{2} ; B$ - woodland adjacent to the plot under consideration from the north. The coordinates of the mark in the image B: 52.476651, 41.452701. URL: https://www.google.ru/maps/@52.4431532,41.4451117,2804m/data=!3m1!1e3 


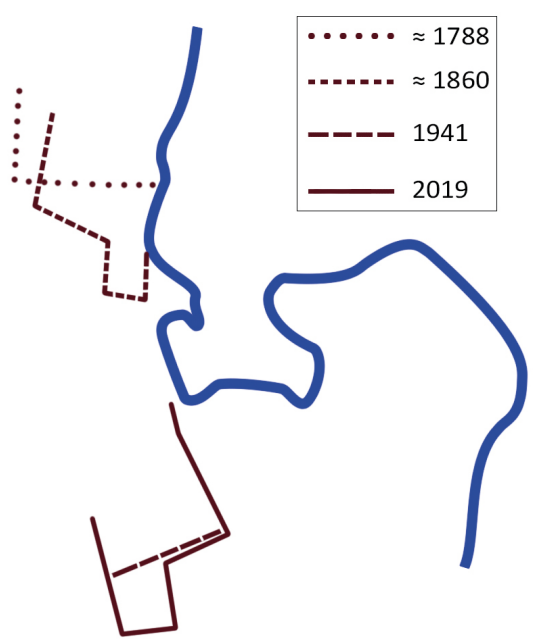

Fig. 10. A scheme of movement of the southern border of the village Vorontsovka along the meander. Compiled by E.S. Grishin
In Fig. 9, it is noticeable that the forest was largely cut down (obviously, in stages) and subsequently restored by humans.

The village of Vorontsovka stretches along the Tsna, which clearly corresponds to its layout. The village has a traditional linear layout; however, according to cartographic sources, the nature of the development demonstrates certain dynamics (Fig. 10). Between the 1860s and 1940s Vorontsovka "sprawled" southwards along the outer side of the meander. One of the possible reasons for this process may have been changes in hydrography in the lower reaches of the Tsna River and the entire adjacent territory. Canals are visible on map RA1941 that were obviously built to drain the area north of Vorontsovka.

Presumably, at the time of Mende-1860, the territories north of Vorontsovka were less wet and swampy. A significant number of relatively small anomalies are noticeable on the floodplain bank ${ }^{31}$, given that people preferred to settle on a high bedrock bank; however, the floodplain bank is a very fertile plain despite being regularly flooded during the spring flood. The spill carried silt from the bottom of the river. This area is very attractive from an economic point of view but not suitable for fundamental buildings. Apparently, we are dealing with numerous traces of temporary, or permanent but destroyed outbuildings, as well as traces of economic and land management activities (these probably include dams and drainage canals).

Object A in Fig. 8 differs in shape from other openings in the forest. We presume that this object is a trace of the influence of military history on the natural environment. A set of anomalies in the forest (Fig. 11, marker A) - due to their configuration and size could have been a military airfield in 1941-1943. Forest airfields were indeed the preferred, albeit time consuming, options. Airfields of that time usually consisted of densely packed soil.

Not far from the Karian-Stroganovo railway station there is another object that is very similar to the remains of a military airfield of another type - an almost circular field with a diameter of $1.3 \mathrm{~km}$ (Fig. 11, marker K). Archival sources ${ }^{32}$ reveal that a decision was made on 23 July 1941 to build an airfield in another location (practically between the two supposed sites). Now (as in 1941) this is an unremarkable piece of agricultural land - the area marked F in Fig. 11. No traces remain. A plan from the source is shown in Fig. 12.

The actual location of military airfields is not known (archival data about their functioning during the Great Patriotic War are still classified). It is known that camouflage was a key problem for military airfields. Engineer-Captain L. Loginov clearly indicated in the

31 See: URL: http://arcg.is/0GeCSy (accessed: 01.08.202).

32 Akt komissii Tambovskogo obkoma VKP(b) ot 23 iiulia 1941 g. o vybore uchastka dlia stroitel'stva aerodroma na territorii Nikol'skogo sel'soveta Znamenskogo raiona i plan voennogo aerodroma // State Archive of Social and Political History of the Tambov Region (GASPITO). F. P-1045. Op. 1. D. 2043. L. 60-61. 


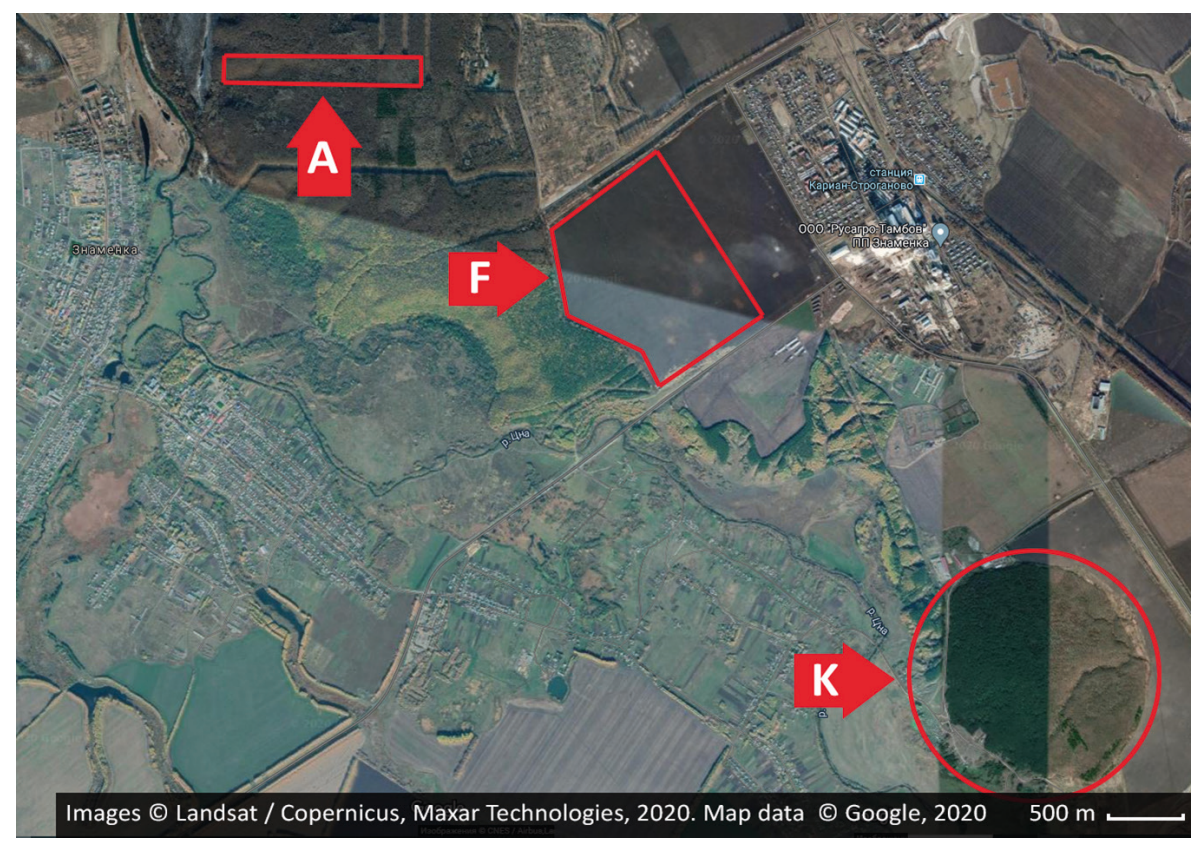

Fig. 11. Satellite imagery obtained via Google Maps. Probable locations of the aerodrome. Markers A, F and K are the supposed locations of the military airfield in 1941-1943. URL: https://www.google.ru/maps/@52.4431532,41.4451117,2804m/data=!3m1!1e3

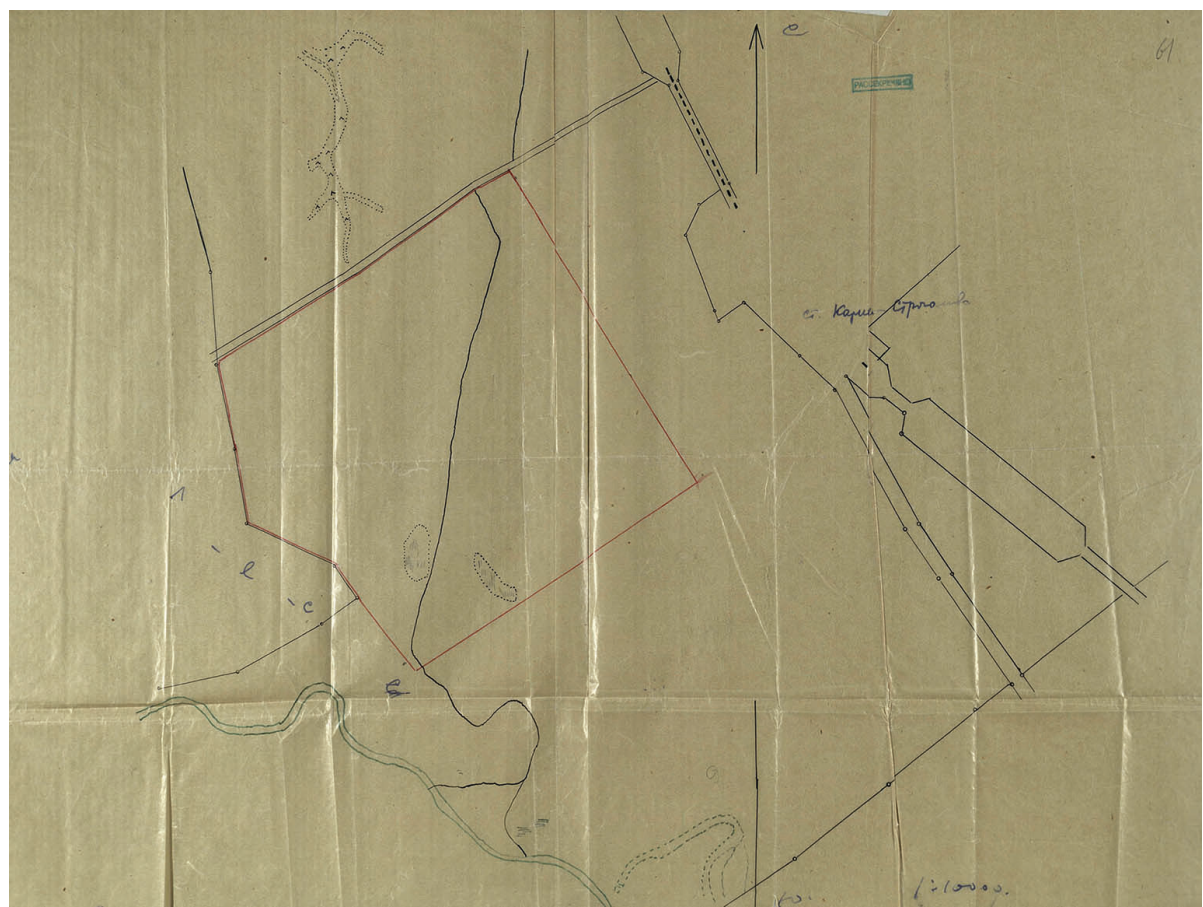

Fig. 12. Aerodrome plan attached to the decision for the construction of the aerodrome [Akt komissii Tambovskogo obkoma VKP(b). L. 61] 


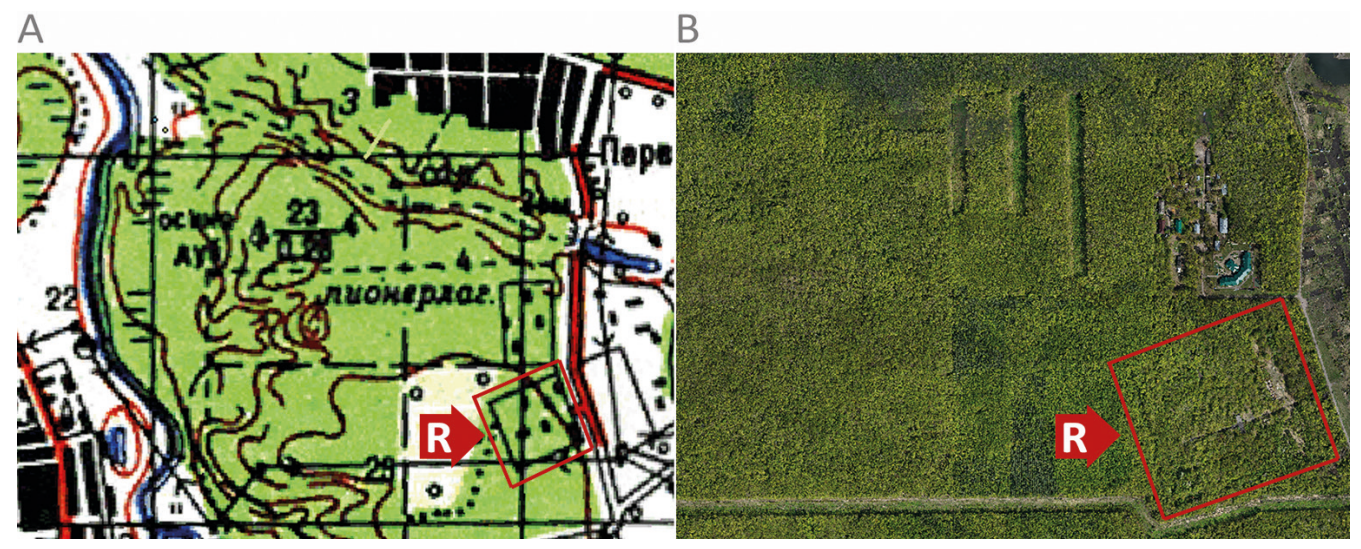

Fig. 13. The military unit (R): $A$ - on the TK-1992 map; $B$ - on the orthophotomap-2019. URL: http://www.etomesto.ru/map-genshtab_n37-g/

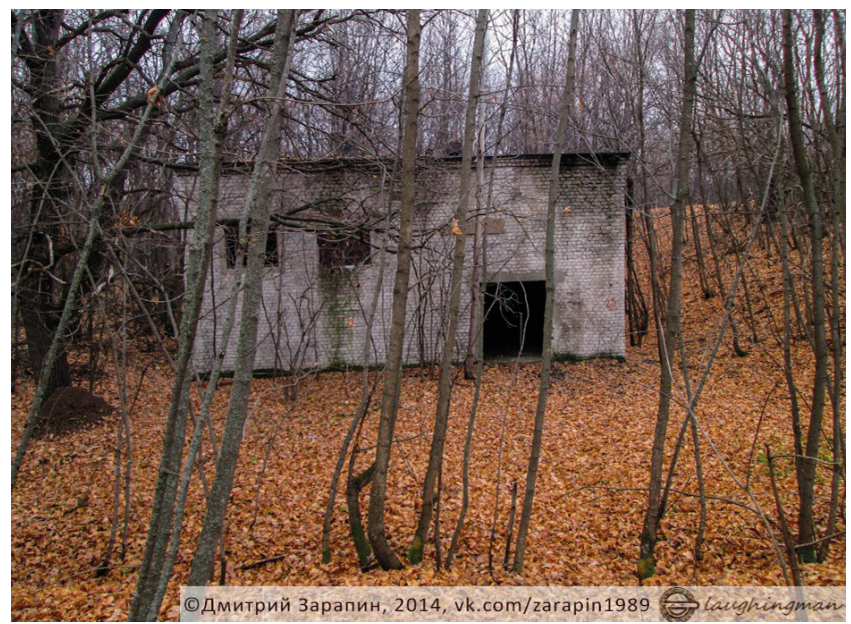

Fig. 14. The condition of the territory of the $237^{\text {th }}$ Guards Anti-Aircraft Missile Regiment, autumn 2014. Photo: D. Zarapin. URL: https://vk.com/zarapin1989

newspaper of the USSR Air Force that fake airfields were built (imitated on the ground) during the construction of real airfields. They served as false targets for the enemy. Perhaps objects A and $\mathrm{K}$ in Fig. 11 are just such fake airfields. In place of these 80-year-old military installations, the original natural environment, typical of an agrarian society, has been restored: the field has become a field, and forestland has become overgrown with forest. The methods we employed, however, made it possible to see anthropogenic footprints in nature.

The TK-1992 map (Fig. 13 A) shows a Young Pioneer camp (marked R) that, in fact, was the location of the 237 th Guards Anti-Aircraft Missile Regiment (Fig. 13). The military unit there was presumably disbanded in 1994. This object had lost its military significance; the territory had been abandoned; and the wild natural environment began to recover. The surrounding forest has largely engulfed the military base (Figs. 13 B, 14). 
In terms of ecological history, it is necessary to establish what kind of forest began to recover around an abandoned artificial object - natural or one growing from seeds brought here by people. In this case, the young regenerating vegetation on the territory of the object is similar in species composition to the surrounding forest (except for the felling adjacent to the west). This allows us to assume that the natural environment which existed here before the human impact is restoring itself. This recovery is also characterised by its high rates: the photograph in Fig. 14 was taken 20 years after the abandonment of the military unit.

\section{Conclusion}

The research has yielded some methodological results that have great heuristic significance. It demonstrated the real possibility of using aerial photographs and satellite images in historical research into the $19^{\text {th }}-20^{\text {th }}$ centuries. Analysing and comparing plans and historical maps, modern aerial photography, field research, and non-cartographic historical sources is instrumental in understanding social history and its driving forces.

It was shown that the processing of remote sensing data:

1) is a good way to set targets for historical research in archives;

2) enables to fill in the gaps of historical sources (maps, written sources), which makes it possible to discover completely new evidence of the past;

3 ) is a powerful tool for the reconstruction of the natural factors that influenced socio-economic history (including the dynamics of resettlement, economic activity and nature management, the development of communications).

The last point is especially important. We can deduce the way that certain natural factors (inextricably linked with geography) have influenced and are affecting people's lives, and vice versa: how humans transform the environment. These two processes are, of course, inseparably connected.

The approaches and tools of geoecological history, as well as those of some natural and exact sciences, can be applied to historical research, in which case the focus of research shifts from changes in landscape to social dynamics considered in interaction with a dynamic natural environment. The environment, within the framework of such approach, is regarded as the context and driving force of socio-economic history; and socio-economic history as the context and driving force of environmental changes. This approach enables to put substantive propositions about socio-economic history, which have found support in this case study, and which, we hope, could be confirmed over larger areas. Resettlement in the plains of the forest steppe was very much dependent on the water regime, which directly affected the state and dynamics of communication routes and economic infrastructure. A striking example of such an impact is the vanished settlement that we discovered. It had emerged along the road and disappeared as a result of swamping of the areas which this road crossed.

The settlements were located close to rivers for many well-known reasons, but lowland rivers dramatically alter the surrounding landscape in relatively short historical periods, and are themselves subject to human impact. Rivers respond to climate change and anthropogenic influence by swamping floodplain lands or drying up. Changes in living conditions and work activities led to variability in settlement patterns and land use. This 
can be seen especially clearly on the low bank, where such schemes were predominantly temporary.

One way to stabilise the environment is to preserve forests in river valleys. The forest in the river valley in the examined plot had been subjected to dramatic human impact since at least the middle of the $19^{\text {th }}$ century. A significant part of the forest was gradually cut down and then recreated piece by piece. Nevertheless, the forest has survived, which indicates a desire to preserve it through many historical eras. The current forest is no longer a remnant of virgin nature but a copy (very distorted) of the original environment created by many generations. The balance of forest and non-forest land types has been maintained for more than two centuries.

Human-made infrastructure and features of the natural environment together form a kind of geometrical context of place. This geometric context affected people's lives and their choices about how to develop their environment. This influence, in some cases, can still be traced even a century after the system-forming elements of this context (for example, settlements, economic infrastructure, roads, borders of land plots, etc.) have lost their original functional significance or even disappeared altogether. A typical example is that people still walk through the forest along a path that was paved as a road to the small village of Erofeevo which disappeared no later than the middle of the $19^{\text {th }}$ century.

\section{References}

Andersen O., Crow T.R., Lietz S. M., Stearns F. Transformation of a landscape in the upper mid-west, USA: The history of the lower St. Croix river valley, 1830 to present. Landscape and Urban Planning, 1996, vol.35, iss. 4, pp. 247-267. https://doi.org/10.1016/S0169-2046(96)00304-0

Budiukina N.N., Glagoleva O.E., Kanishchev V.V., Mizis Iu. A. Istochnikovedcheskii analiz istoricheskikh dokumentov kak informatsionnogo potentsiala dlia komp'iuternoi rekonstruktsii russkoi dvorianskoi usad'by kontsa XVIII - nachala XX v. (po materialam Tambovskoi i Tul'skoi gubernii). Vestnik Tambovskogo universiteta. Seriia: Gumanitarnye nauki, 2013, iss. 1, pp.256-269. (In Russian)

Budiukina N. N., Kanishchev V.V., Konchakov R. B., Konchakov R. B., Mizis Iu. A. Prirashchenie istoricheskikh znanii v protsesse elektronnoi rekonstruktsii pamiatnikov istorii i kul'tury (po materialam dvorianskikh usadeb Tambovskoi gubernii). Vestnik Tambovskogo universiteta. Seriia: Gumanitarnye nauki, 2013, iss. 12, pp.411-419. (In Russian)

Bürgi M., Hersperger A. M., Schneeberger N. Driving forces of landscape change - current and new directions. Landscape Ecology, 2004, vol. 19, iss. 8, pp. 857-868. https://doi.org/10.1007/s10980-004-0245-8

Bürgi M., Russell E. W. B. Integrative methods to study landscape changes. Land Use Policy, 2001, vol. 18, iss. 1, pp. 9-16. https://doi.org/10.1016/S0264-8377(00)00041-7

Bürgi M., Straub A., Gimmi U., Salzmann D. The recent landscape history of Limpach valley, Switzerland: Considering three empirical hypotheses on driving forces of landscape change. Landscape Ecology, 2010, vol.25, iss. 2, pp. 287-297. https://doi.org/10.1007/s10980-009-9412-2

Grossinger R. M., Striplen C. J., Askevold R. A., Brewster E., Beller E. E. Historical landscape ecology of an urbanized California valley: wetlands and woodlands in the Santa Clara Valley. Landscape Ecology, 2007, vol.22, iss. 1, pp. 103. https://doi.org/10.1007/s10980-007-9122-6

Khmel' E. V. Formirovanie ratsional'nogo prirodopol'zovaniia $v$ khoziaistvakh krupnykh zemlevladel'tsev Tambovskoi gubernii v kontse XIX - nachale XX vv. Diss. ... kand. ist. nauk. Tambov, 2004, 245 p. (In Russian)

Korobov D. S. Primenenie GIS i dannykh distantsionnogo zondirovaniia v arkheologii. Mezhdistsiplinarnaia integratsiia $v$ arkheologii. Moscow, Institute of Archeology RAS Press, 2016, pp. 280-311. (In Russian)

Levin N., Kark R., Galilee E. Maps and the settlement of southern Palestine, 1799-1948: An historical/ GIS analysis. Journal of Historical Geography, 2010, vol.36, iss. 1, pp.1-18. https://doi.org/10.1016/j. jhg.2009.04.001 
López García J., Prado Molina J., Manzo Delgado L., Peralta Higuera A. Monitoring changes of forest canopy density in a temperature forest using high-resolution aerial digital photography. Investigaciones Geográficas, Boletín del Instituto de Geografía, 2016, vol.2016, iss.90, pp.59-74. https://doi.org/10.14350/ rig. 47360

Machar I., Servus M. Linking historical research with restoration ecology in the floodplain landscape case study: Landscape-ecological study and management plan of the Tovačov lakes (Czech Republic). Journal of Landscape Ecology, 2010, vol.3, iss. 1, pp. 16-41. https://doi.org/10.2478/v10285-012-0021-4

Mackovčin P. Land use categorization based on topographic maps. Acta Pruhoniciana, 2009, vol. 91, pp. 5-13.

Morgan J.L., Gergel S.E., Coops N.C. Aerial photography: A rapidly evolving tool for ecological management. BioScience, 2010, vol. 60, iss. 1, pp.47-59. https://doi.org/10.1525/bio.2010.60.1.9

Murav'ev N.I. Izbrannye kraevedcheskie trudy, vol.1. Tambov, Tambovskii vestnik Publ., 2006. 480 p. (In Russian)

Pindozzi S., Cervelli E., Capolupo A., Okello C., Boccia L. Using historical maps to analyze two hundred years of land cover changes: Case study of Sorrento peninsula (south Italy). Cartography and Geographic Information Science, 2016, vol. 43, iss. 3, pp. 250-265. https://doi.org/10.1080/15230406.2015.1072736

Santana-Cordero A. M., Monteiro-Quintana M.L., Hernández-Calvento L. Reconstruction of the land uses that led to the termination of an arid coastal dune system: The case of the Guanarteme dune system (Canary Islands, Spain), 1834-2012. Land Use Policy, 2016, vol. 55, pp. 73-85. https://doi.org/10.1016/j. landusepol.2016.02.021

Santana-Cordero A.M., Szabó P. Exploring qualitative methods of historical ecology and their links with qualitative research. International Journal of Qualitative Methods, 2019, vol. 18, pp. 1-11. https://doi. org/10.1177/1609406919872112

Santana-Cordero A., Monteiro-Quintana M.L., Hernández-Calvento L. Reconstructing the environmental conditions of extinct coastal dune systems using historical sources: The case of the Guanarteme dune field (Canary Islands, Spain). Journal of Coastal Conservation, 2014, vol. 18, iss. 4, pp. 323-337. https:// doi.org/10.1007/s11852-014-0320-5

Skaloš J., Engstová B. Methodology for mapping non-forest wood elements using historic cadastral maps and aerial photographs as a basis for management. Journal of Environmental Management, 2010, vol.91, iss. 4, pp. 831-843. https://doi.org/10.1016/j.jenvman.2009.10.013

Skaloš J., Engstová B., Trpáková I., Šantrůčková M., Podrázský V. Long-term changes in forest cover 17802007 in central Bohemia, Czech Republic. European Journal of Forest Research, 2012, vol. 131, iss. 3, pp. 871-884. https://doi.org/10.1007/s10342-011-0560-y

Song X., Huang Y., Fu J., Jiang D., Tian G. Spatial variability and ecological effects of anthropogenic activities in a nature reserve: A case study in the Baijitan National Nature Reserve, China. Sustainability, 2017, vol. 9, iss. 2, pp. 1-14. https://doi.org/10.3390/su9020239

Velli A., Pirola A., Ferrari C. Evaluating landscape changes using vegetation and land-use maps: An integrated approach. Landscape Research, 2019, vol.44, iss. 6, pp.768-781. https://doi.org/10.1080/0 1426397.2018.1513128

Wan L., Zhang Y., Zhang X., Qi S., Na X. Comparison of land use/land cover change and landscape patterns in Honghe National Nature Reserve and the surrounding Jiansanjiang Region, China. Ecological Indicators, 2015, vol.51, pp. 205-214. https://doi.org/10.1016/j.ecolind.2014.11.025

Zhukov D.S., Lyamin S.K., Kunavin K.S. Experience in using aerial photography and historical maps in historical research: Literature, methods, cases. Innovatika i ekspertiza, 2019, iss. 3 (28), pp.44-63. https://doi.org/10.35264/1996-2274-2019-3-44-63 (In Russian)

Zhurbin I.V., Borisov A.V., Nazmutdinova A.I., Milich V.N., Petrov R.P., Ivanova M.G., Modin R.N., Kniazeva L. F., Vorobeva N. G., Zinchuk S. V. The use of remote sensing, geophysical methods and soil analysis in the study of sites disturbed by agricultural activity. Arkheologiya, etnografiya i antropologiya Yevrazii, 2019, vol.47, iss. 2, pp.103-111. https://doi.org/10.17746/1563-0102.2019.47.2.103-111 (In Russian)

Статья поступила в редакцию 10 августа 2020 г. Рекомендована в печать 25 мая 2021 г. Received: August 10, 2020 Accepted: May 25, 2021 